Article

\title{
Decrypting the Belt and Road Initiative: Barriers and Development Paths for Global Logistics Networks
}

\author{
Benjamin Nitsche \\ Chair of Logistics, Berlin University of Technology, 10623 Berlin, Germany; nitsche@logistik.tu-berlin.de
}

Received: 12 October 2020; Accepted: 30 October 2020; Published: 2 November 2020

\begin{abstract}
The Belt and Road Initiative (BRI) is an ambitious infrastructure and development project promoting sustainable economic growth through facilitating prosperous trade across Eurasia and Africa; however, its potential remains underexploited. Logistics networks along BRI routes face several challenges that hinder efficient operations. In addition, although uncertain of how the initiative will develop, logistics and supply chain management (LSCM) practitioners must align their networks with future developments. This study aims to synthesize current barriers to the BRI from an LSCM perspective; propose strategies for dealing with them; and outline and assess conceivable BRI development scenarios to create awareness for possible international logistics network developments. The study builds on a structured and moderated Nominal Group Technique exercise among 15 LSCM professionals to extract current barriers, mitigation strategies, and potential development scenarios, followed by a survey among 52 LSCM professionals to assess those issues. The study synthesizes and assesses 17 BRI barriers for LSCM practice and proposes 20 strategies for dealing with them, assessed in terms of effectiveness and complexity. Moreover, 14 development scenarios are assessed in terms of their probability of becoming reality and impact on the vulnerability of logistics networks, categorized into four scenario clusters (monitor, prepare, propel, and exploit) for guiding LSCM practice.
\end{abstract}

Keywords: Belt and Road Initiative; New Silk Road; One Belt One Road; international logistics networks; Nominal Group Technique; scenario analysis

\section{Introduction}

The ancient Silk Road was a vast network of land and sea trade routes connecting Europe, Asia, and Africa and facilitating trade and cultural exchanges from the second century BCE to the 18th century [1]. In 2013, mindful of the history of this ancient trade network, the Chinese President, Xi Jinping, introduced a national strategy, then called the New Silk Road and later known as the Belt and Road Initiative (BRI) [2], one of the biggest infrastructure projects in the world, with over US\$900 billion of investment in road, rail, gas, oil, and port infrastructure to connect the entire Eurasian world and Africa, covering $64 \%$ of the global population and $30 \%$ of the world GDP [3,4].

There are different ideas, opinions and discussions on China's motivation behind the BRI. One could argue that it is to sustain China's economic growth by better connecting existing markets and opening up to new markets, which is also reflected by Chinese foreign direct investments in these markets. It could also be argued that the main purpose may be to improve the country's international economic influence, but this is also accompanied by the creation of geopolitical influence that can be used opportunistically by China [5,6]. This could be the case, for example, when capital loans have been granted by China (i.e., through the Asian Infrastructure Investment Bank), for infrastructure development in a certain BRI-related country, but are difficult to repay by the debtor. There are also others that argue that an additional major motivation of China behind the BRI might be getting long-term access to the natural resources of Africa and Central Asia [7,8]. Without delving into 
these and further potential motivations behind the BRI, it can be concluded that there are multiple, interrelated reasons for its creation.

However, what is certain is that the BRI connects numerous countries on three large continents and thereby provides the potential for increased trade among those regions. Because of the direct linkage to trade facilitation, it is argued that the BRI contributes to the UN Sustainable Development Goals (SDGs), as both are "mutually supportive development agendas" (cf. [9]). The supportive nature of the BRI contributing to the SDGs is mainly stated due to the assumption that the BRI focusses on encouraging more efficient trade, which consequently can lead to the economic growth of the involved parties. Previous research has also indicated that the BRI provides the potential to positively impact the sustainable development of the countries involved through increased trade [10-13]. However, it must be stated that this refers to economic sustainability, which is the main focus of the BRI-ecological and social sustainability perspectives are mostly out of scope when relating the BRI and SDGs, and in-depth analyses on the connection of the initiatives are still missing [14]. These previous studies also confirm that due to the novelty of the BRI and the lack of available data, the assessment is not possible at this stage, since economic development can only be determined from a long-term perspective. Additionally, previous studies indicate that the BRI might positively impact economic growth among the countries involved, but benefits are not shared equally, considering that China seems to profit even more from the cooperation [15]. Nevertheless, the BRI can be a win-win scenario for all countries involved if current challenges are tackled and barriers are removed. Owing to its global importance, the BRI has captured the interest of researchers, thereby leading to a wide range of research on the initiative and its effects at multiple levels [16-21], that often focuses on the macroeconomic assessment of the initiative and the effects related to it. To ensure the long-term success of the BRI and the economic growth of the countries involved, logistics is considered as a "driving force" [22]. This being said, without enabling efficient logistics along the BRI paths the success of the initiative is in jeopardy. Remarkably, given its clear implications for global supply chains [23-25], the BRI has received only limited attention in the logistics and supply chain management (LSCM) literature compared with other domains [26,27]. Although LSCM researchers can support global supply chains by investigating the implications of the BRI, so far, they have largely failed to do so.

BRI is one of the most ambitious logistics and infrastructure initiatives of this century, and its implementation may impact on LSCM practitioners located on BRI routes. Moreover, companies must prepare for an uncertain future, as the initiative is more of a fluid concept than a clearly formulated plan with precisely determined developments, and that provides uncertainties for the countries and companies involved [28-31]. LSCM practitioners are seeking assistance to understand the initiative and its future implications for global supply chains, so that they can tackle the barriers, leverage the full potential of the BRI, and ensure continued, efficient material flows.

To bridge this gap between research and practice, which is frequently discussed in the management literature [32-35], a comprehensive understanding of the barriers that the BRI presents to efficient operations is needed, and the possible future developments of the BRI must be outlined. By shedding light on this area, this study will identify additional BRI-related fields in which research can support practice. This study aims, therefore, to contribute to the following research objectives (RO):

RO1: Outline and assess the current barriers that the BRI presents, from an LSCM perspective, that inhibit efficient operations along BRI paths.

RO2: Provide indications of strategies for dealing with current BRI barriers.

RO3: Propose and assess future development scenarios for the BRI.

To contribute to these ROs, this study follows a two-stage approach. First, a moderated on-site group exercise with 15 professionals with long-standing experience in LSCM is performed to systematically extract current barriers to the BRI and potential strategies for dealing with them, as well as to propose potential development scenarios of the BRI. Second, an additional follow-up survey among 52 LSCM professionals is done to assess the barriers by importance; the strategies by complexity 
and effectiveness; and the development scenarios by probability and their impact on the vulnerability of logistics networks. The group exercise builds on the Nominal Group Technique (NGT), which is a structured moderated group exercise process that separates problem description and problem solution seeking to reduce the biases of traditional group exercise formats [36]. To synthesize the results, the researchers apply the Q-methodology [37], which is a bottom-up approach to condense a variety of factors to overarching meta-factors in a structured way, and which has also been applied in LSCM research [38]. Additionally, different measures to reduce bias throughout the various stages of the research process have been taken. The study, and the results obtained, are limited to European-Chinese logistics networks. Although Africa is playing an essential role in the BRI, the European-Chinese trade relationship remains dominant in this trilateral network. The logistics barriers are very different when African countries are included, and Africa therefore remains beyond the scope of this study. Moreover, the results gained through this analysis represent the regional view of companies mostly operating in networks between Central Europe and China, which is one of the most important trade relationships in the BRI context. Equally important views of Southern European, Central Asian, and other stakeholders have not been included in the analysis.

\section{Background of the Belt and Road Initiative}

Before China started its economic reform in the 1970s, it was a small agriculture-based economy. In the early decades of this reform, China tried to focus on reforming the domestic market and was not too much involved in international affairs. However, due to an increasing focus on manufacturing labor-intensive goods for the international market, China developed into one of the biggest economies and trade partners in the world [4]. This opening up to international affairs is also evident in the development of China's five-year plans. The BRI, which was initially presented by Xi Jinping in 2013, is a prominent part of China's 13th five-year plan (2016-2020) for economic development. This shows the importance of the initiative for China and is, from China's point of view, a consistent step in opening up to even more international trade and the global interlinking of value chains.

Before outlining the current barriers to BRI, the strategies for dealing with them, and future development paths from an LSCM perspective, the overall BRI network must first be explained. The BRI comprises investments in infrastructure projects seeking to develop the Maritime Silk Road (MSR) and six economic corridors (EC) within the Eurasian region, as outlined by the National Reform and Development Commission of China [39]. These ECs connect different Eurasian countries with one another and also connect them to the MSR. That said, from a logistics perspective, both infrastructure dimensions-ECs and the MSR - must be analyzed together.

The MSR describes a vision of a better-connected maritime transport network in Eurasia, achieved by investing in port infrastructure in China, Southeast Asia, India, the Middle East, and Europe [23]. For European-Chinese logistics networks-the focus of this study-port infrastructure investments in European ports are of clear importance, as they could impact on future maritime transport routes between China and Europe [40]. In this regard, the ports of Piraeus, Greece, and Venice, Italy, form prominent developments that could provide viable future options for trade between China and Europe through the Suez Canal. To provide viable competition to northern European seaports, the BRI plans to connect the Piraeus via a high-speed rail connection to Central European rail tracks already in use for rail transport between Europe and China [41].

In order to outline the current state and potential future developments of rail transportation between China and the rest of the world, the ECs need to be explained. Three of these are relevant to transporting goods via rail between China and Europe. First, the China-Mongolia-Russia EC connects China with the Russian railway system via Mongolia [39]. Using this connection, goods moving between China and Europe can be transported through Moscow (Russia) to Brest (Belarus) and on to Central Europe, e.g., Duisburg, Germany $[28,41]$. Second, the New Eurasia Land Bridge EC is a direct rail connection between China (Jiangsu Province) and the Port of Rotterdam, The Netherlands, via Dostyk (Kazakhstan), Moscow (Russia), and Brest (Belarus) through to Poland and Duisburg, Germany. 
Third, the China-Central Asia-West Asia EC seeks to develop a connection for Central Asian countries such as Kazakhstan, Kyrgyzstan, Tajikistan, Iran, and Turkey. For goods in transit from China to Central Europe, this line provides a third option with a more direct connection to southern Europe via Istanbul (Turkey) and also to Central Europe via Brest (Belarus), utilizing the same rail infrastructure in Eastern Europe as the previously mentioned corridors [28,30,41]. The remaining three ECs-China-Pakistan, Bangladesh-China-India-Myanmar and China-Indochina-Peninsula-predominantly serve to connect the remaining South and South-East Asia region with China and also to connect participating countries to the MSR [23]. However, those ECs are developing in a different way, and the choice of a certain transport route is determined by several characteristics (e.g., transport times and transport modes, among others) and needs case-specific analyses [42].

Although the strategy for the ECs and MSR has been clearly communicated, the projects and investments developing them are diverse and hard to keep track of. A recent investigation showed that the implementation of the BRI is less coordinated than intended and a large proportion of the infrastructure projects are taking place outside the ECs and the MSR [30]. Therefore, the BRI is better understood as a fluid concept with a long-term vision rather than a project with a clear top-down strategy and execution [28,29]. Moreover, for rail transportation, there is no holistic optimization and coordination of transport along the three main rail corridors with the Chinese rail network, thus leading to insufficient cargo handling capacity [43].

Cooperation between Europe and China regarding the BRI and its development is increasing, although there is room for improvement in various areas [44]. The literature mentions several barriers that are currently dampening the sustainable development of the BRI, such as volatile and uncertain legal and administrative environments, border and customs barriers, political risks along BRI routes, and shortage of qualified personnel, but also infrastructure barriers, such as the insufficient transport and processing capacity of the railway infrastructure $[45,46]$. Companies operating in European-Chinese logistics networks need knowledge of the development of future transportation routes to prepare their businesses and supply chains accordingly. Nevertheless, LSCM literature on the BRI and its barriers is sparse [26,27]. In order to create a more comprehensive picture of recent BRI developments and their implications for future LSCM, this study seeks to outline the current barriers to, strategies for, and development scenarios of the BRI.

\section{Research Design}

To contribute to the ROs stated above, the study follows a two-stage research process. In the first stage, current BRI barriers are synthesized, strategies dealing with them are derived, and potential development scenarios of the BRI are developed, building on a moderated group exercise with 15 LSCM practitioners performed at the end of September 2019. The group exercise was performed using the NGT, a rigorous group exercise process for systematically extracting practitioners' knowledge that outperforms traditional group exercise techniques such as focus groups $[47,48]$. The NGT process consists of two stages-problem description and problem solution-that are performed by the same group of people. Through this moderated process, for both stages, participants are first asked to individually generate ideas according to a certain question. These ideas are subsequently shared within the group applying the round-robin procedure in order to ensure that every participant of the group exercise can contribute equally. The detailed process will be described in the following (Section 3.1). The participating practitioners in the group exercise were specifically invited to discuss the current state of, and development paths for, the BRI. Throughout the group exercise, different measures were taken to reduce bias and encourage every participant to contribute equally. The same group of practitioners was also utilized to develop potential development scenarios of the BRI. In the second stage, identified barriers and strategies as well as development scenarios were assessed according to certain characteristics that will be further described in the later part of this chapter. The assessment was done by 52 LSCM professionals through an online survey. The detailed research procedure is outlined in Figure 1 and explained in detail below. 

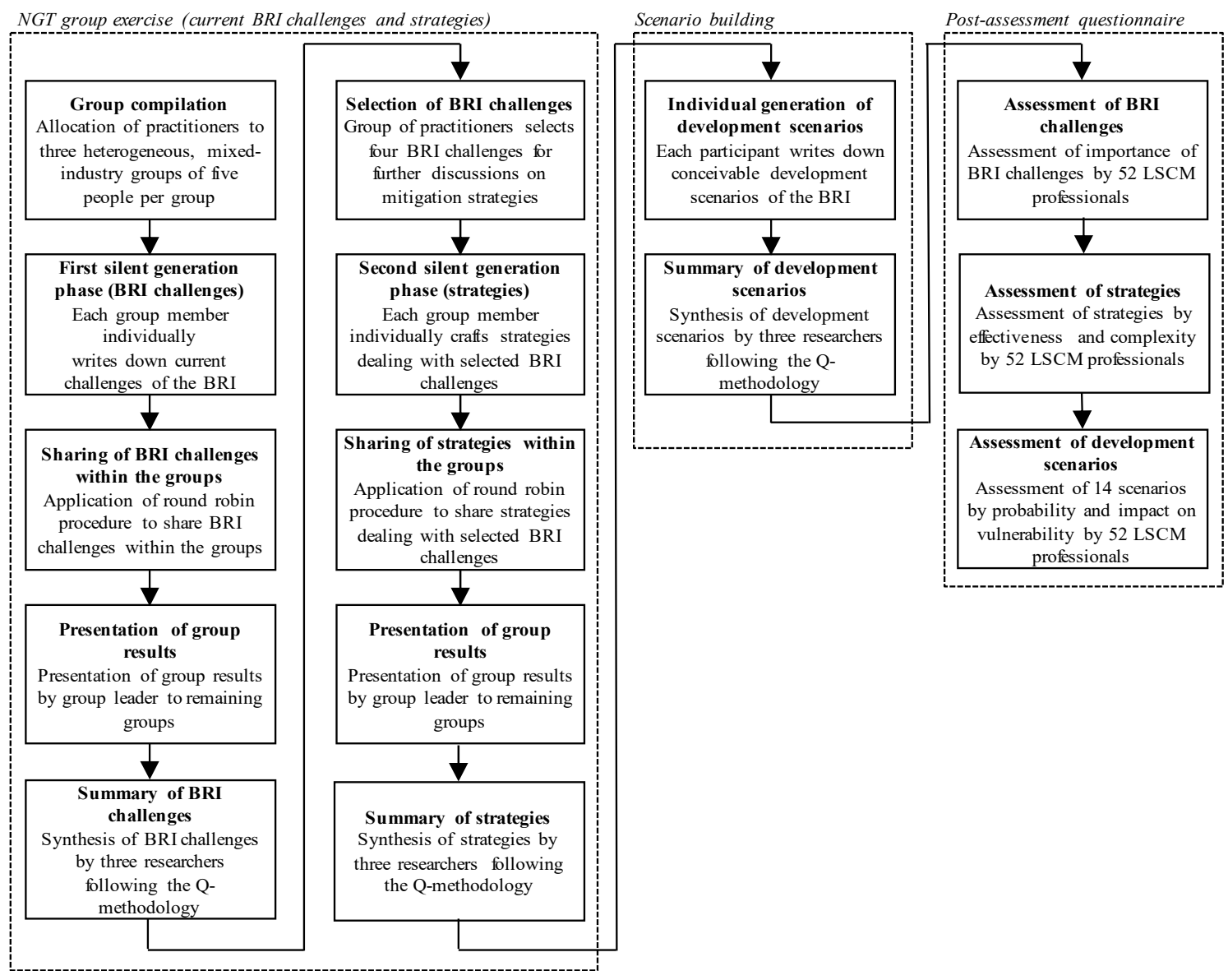

Figure 1. Research procedure.

\subsection{First Stage: Group Exercise to Derive BRI Barriers, Strategies, and Development Scenarios}

BRI barriers and strategies: In the first part of the group exercise, NGT [36,48] was performed to identify current barriers of the BRI that inhibit efficient operations along the BRI corridors (RO1) as well as to develop strategies for dealing with those barriers (RO2). The NGT clearly separates the problem description from the problem solution and has been utilized in LSCM research for extracting practitioners' knowledge on complex problems in a structured way [38,49-51]. The separation of the problem description and the problem solution also seeks to mitigate the shortcomings of other expert group exercises, such as Delphi studies or focus groups [47]. Traditional focus groups can assist in extracting experts' knowledge on a certain topic; however, a problem is that very self-confident group members can dominate the discussion, thus preventing less self-confident members from contributing equally, which can lead to bias. Delphi studies tackle this issue by not allowing face-to-face meetings, thus leading to more equal contributions from all participants [47]. Nevertheless, the absence of face-to-face meetings and discussions prevents any exchange of views or joint idea generation. The NGT seeks to mitigate the shortcomings of both these types of studies by allowing group members to meet, but encouraging all members to contribute equally to the exchange through a structured and moderated process [52,53].

Although NGT guidelines do not prescribe a definite minimum or maximum number of group members, previous LSCM research has found that on-site groups of 8 to 23 participants, separated into sub-groups, are appropriate $[38,51]$. In assembling the total study group, the researchers intended to bring together a heterogenous group of experienced practitioners from different industries and supply-chain positions to cover different views on the BRI. Most practitioners participating in this study have long-standing practical experience-an average of 15 years of professional experience 
in LSCM-mostly in leading positions in their respective companies, in which they are responsible for international logistics networks in contact with the BRI. Each participant was dealing with European-Chinese logistics networks on a daily basis and stated that they were familiar with current BRI developments, as the BRI is important for their companies' logistics networks. Table 1 outlines the sample demographics. Most of the participants represent companies with over 2500 employees and annual turnovers of over $€ 500$ million. All companies are based in Central Europe (mostly Germany) but operate globally. A discussion on the limitations and implications of the group sample is presented in the final remarks section.

Table 1. Overview of sample demographics for the group exercise.

\begin{tabular}{|c|c|c|c|c|c|}
\hline$\#$ & Industry Type & $\begin{array}{l}\text { Total Number } \\
\text { of Employees }\end{array}$ & $\begin{array}{l}\text { Annual } \\
\text { Turnover }\end{array}$ & $\begin{array}{c}\text { Participant } \\
\text { Management Level }\end{array}$ & $\begin{array}{l}\text { Years of Professional } \\
\text { Experience in LSCM }\end{array}$ \\
\hline 1 & Retailer & $\begin{array}{l}\text { More than } \\
10,000\end{array}$ & $€ 5-10$ bn & Department manager & 19 \\
\hline 2 & $\begin{array}{l}\text { Logistics service } \\
\text { provider }\end{array}$ & $2500-5000$ & $€ 250-500 \mathrm{~m}$ & Executive assistant & 4 \\
\hline 3 & $\begin{array}{l}\text { Logistics service } \\
\text { provider }\end{array}$ & $5000-10,000$ & $€ 1$ bn-2.5 bn & Department manager & 13 \\
\hline 4 & Association & Up to 50 & Up to $€ 10 \mathrm{~m}$ & General manager & 6 \\
\hline 5 & $\begin{array}{l}\text { Logistics service } \\
\text { provider }\end{array}$ & $1000-2500$ & $€ 250-500 \mathrm{~m}$ & Team member & 4 \\
\hline 6 & Consulting & Up to 50 & Up to $€ 10 \mathrm{~m}$ & General manager & 10 \\
\hline 7 & $\begin{array}{l}\text { Logistics service } \\
\text { provider }\end{array}$ & $\begin{array}{l}\text { More than } \\
10,000\end{array}$ & Above $€ 10$ bn & Department manager & 6 \\
\hline 8 & $\begin{array}{l}\text { Logistics service } \\
\text { provider }\end{array}$ & $250-500$ & $€ 500-1000 \mathrm{~m}$ & Team leader & 10 \\
\hline 9 & $\begin{array}{c}\text { Manufacturing, } \\
\text { Machinery/equipment }\end{array}$ & $\begin{array}{c}\text { More than } \\
10,000\end{array}$ & $€ 5-10$ bn & Team leader & 22 \\
\hline 10 & $\begin{array}{l}\text { Logistics service } \\
\text { provider }\end{array}$ & $\begin{array}{l}\text { More than } \\
10,000\end{array}$ & $€ 2.5-5 \mathrm{bn}$ & Team member & 25 \\
\hline 11 & $\begin{array}{l}\text { Logistics service } \\
\text { provider }\end{array}$ & $5000-10,000$ & $€ 5-10$ bn & Department manager & 10 \\
\hline 12 & $\begin{array}{l}\text { Manufacturing, } \\
\text { Electronics }\end{array}$ & $50-250$ & $€ 10-50 \mathrm{~m}$ & Department manager & 12 \\
\hline 13 & $\begin{array}{l}\text { Logistics service } \\
\text { provider }\end{array}$ & $2500-5000$ & $€ 1-2.5$ bn & General manager & 30 \\
\hline 14 & $\begin{array}{l}\text { Manufacturing, } \\
\text { Electronics }\end{array}$ & $\begin{array}{l}\text { More than } \\
10,000\end{array}$ & Above $€ 10$ bn & Department manager & 20 \\
\hline 15 & $\begin{array}{l}\text { Logistics service } \\
\text { provider }\end{array}$ & Up to 50 & Up to $€ 10 \mathrm{~m}$ & General manager & 39 \\
\hline
\end{tabular}

For this study, a group of 15 LSCM practitioners was split into three sub-groups of five participants to apply the NGT to identify current BRI barriers as well as strategies for dealing with them. As proposed in the NGT guidelines, an independent researcher moderated each group and was responsible for the compliance with the NGT process and rules.

In the first phase-problem description —each group member, during a silent generation period, had to individually think for him or herself of current barriers relating to the BRI between Europe and China that inhibit efficient operations, writing each barrier on one card. Afterwards, the group applied a round-robin procedure in which one group member read one barrier out loud and explained it, followed by the next member reading and explaining another. This process went on until all the cards had been read and explained. Throughout this process, discussions on the barriers were forbidden; only questions for understanding the barrier could be asked by the group members, thus enabling 
all group members to contribute equally [36]. The moderators monitored the compliance with the rules. After collecting and summarizing the proposed barriers, each sub-group presented their results to the others. Subsequently, a group of three researchers (the group moderators) applied the Q-methodology [37] to synthesize all the barriers to provide a common basis for further discussions. To perform the Q-methodology, the researchers followed the following procedure: Building on the set of barriers identified by all three groups and written down on single cards, each researcher individually read each card and placed it on an existing card if there was an overlap, or opened a new category if there was no overlap with already placed cards, until all the cards were allocated. Subsequently, each researcher proposed a synthesized set of barriers. Similarities and differences were discussed among the researchers. Through this comparison and discussion process, a condensed, unified version containing 17 BRI barriers was generated.

To initiate the second phase of the NGT-problem solution (which was done using the same group of 15 LSCM practitioners, as proposed by the NGT guidelines) - it was necessary to prioritize barriers that should be discussed further, as, owing to the framing conditions of this group exercise, developing strategies for all 17 BRI barriers was not possible. Therefore, each group member was asked to select four barriers for which he/she would like to develop strategies. This was done because some barriers could have been seen as very important but, from a practitioner's point of view, could not be readily tackled or controlled by strategies that individuals or groups of companies could develop. All individual nominations per barrier were counted, and the four barriers with the most nominations were selected for the second NGT phase.

The second phase-problem solution-followed the same procedure as the first phase. For each of the four barriers, during a silent generation period, each group member first had to individually think of strategies that could assist in solving or mitigating the corresponding barrier. Subsequently, for each of the four barriers, the strategies developed were shared within the sub-groups and the round-robin procedure applied without discussing them in detail. After collecting and summarizing the strategies within the groups, each group presented their result to the assembly. As in the problem description phase, the group of three researchers now synthesized and summarized the strategies developed using the Q-methodology, thus leading to a set of strategies for each of the four barriers chosen by the group.

Scenario building: Owing to the importance of the BRI for European-Chinese logistics networks, an assessment of conceivable future developments of the BRI is important for companies operating in the corresponding rail and maritime corridors. Therefore, the same group of professionals was also utilized to craft potential development scenarios for the BRI. Therefore, each participant, during a third silent generation period, was first asked to think of conceivable development scenarios for the BRI between Europe and China and write each of them down on a single card. Practitioners were asked to think open-mindedly into different directions, such as infrastructure development, regulation, political change, future transport routes, pricing developments, and many more. Subsequently, all the scenarios were shared within the group following the round-robin procedure, again preventing any discussion of the scenario. The researchers then collected all the cards/scenarios and performed a third Q-methodology workshop to synthesize the scenarios developed. As a result, the group of researchers proposed a set of 14 scenarios based on the practitioners' input.

\subsection{Second Stage: Assessment of BRI Barriers, Strategies, and Development Scenarios}

The aim of the second stage was to assess the results of the previous group exercise, utilizing a larger set of practitioners to derive more conclusions for practice, i.e., on which barriers and strategies to focus and how to prepare for particular development scenarios. The assessment was done by a set of 52 LSCM practitioners through an online survey that was sent out to 477 LSCM practitioners. The initial set of 477 LSCM practitioners contacted belongs to a group that participates regularly in workshops, discussions, and other formats on crucial topics in international logistics networks, with a special focus on European-Chinese logistics networks. Therefore, they were assessed as appropriate in terms of content and expertise for participation in this survey. The response rate of $11 \%$ can be seen as 
reasonable owing to ever-declining response rates in LSCM research [54,55]. The questionnaire exercise took place in March 2020. Participants were asked not to include current developments relating to the Coronavirus pandemic in their assessments, as the initial group exercise was conducted in September 2019, when the pandemic was not yet relevant, and the results would otherwise be biased. The sample demographics of the questionnaire participants are outlined in Table 2.

Table 2. Sample demographics of questionnaire participants.

\begin{tabular}{|c|c|c|c|}
\hline Industry Type & Annual Turnover & $\begin{array}{l}\text { Total Number of } \\
\text { Employees }\end{array}$ & $\begin{array}{c}\text { Participants' } \\
\text { Management Level }\end{array}$ \\
\hline $\begin{array}{l}\text { Logistics service } \\
\text { provider|n }=19\end{array}$ & Up to $50 \mid \mathrm{n}=4$ & Up to $10 \mathrm{~m} € \mid \mathrm{n}=4$ & Team member|n $=6$ \\
\hline Retailer|n $=3$ & $50-250 \mid n=4$ & $10-50 \mathrm{~m} € \mid \mathrm{n}=3$ & Team leader $\mid \mathrm{n}=5$ \\
\hline $\begin{array}{l}\text { Manufacturing, Consumer } \\
\text { goods } \mid \mathrm{n}=2\end{array}$ & $250-500 \mid \mathrm{n}=4$ & $50-250 m € \mid n=5$ & $\begin{array}{c}\text { Department } \\
\text { manager|n = 24 }\end{array}$ \\
\hline $\begin{array}{l}\text { Manufacturing, Chemicals } \\
\& \text { Pharmaceuticals } \mid \mathrm{n}=2\end{array}$ & $500-1000 \mid \mathrm{n}=5$ & $250-500 m € \mid n=6$ & General manager $\mid \mathrm{n}=15$ \\
\hline $\begin{array}{c}\text { Manufacturing, } \\
\text { Automotive } \mid \mathrm{n}=8\end{array}$ & $1000-2500 \mid n=3$ & $500-1000 m € \mid n=5$ & $\begin{array}{l}\text { Member of the } \\
\text { board|n }=2\end{array}$ \\
\hline $\begin{array}{l}\text { Manufacturing, } \\
\text { Electronics } \mid \mathrm{n}=5\end{array}$ & $2500-5000 \mid n=6$ & 1 bn-2.5 bn $€ \mid \mathrm{n}=7$ & \\
\hline $\begin{array}{c}\text { Manufacturing, } \\
\text { Machinery/equipment } \mid \mathrm{n}=8\end{array}$ & $5000-10,000 \mathrm{n}=3$ & 2.5 bn -5 bn $€ \mid n=2$ & \\
\hline $\begin{array}{l}\text { Manufacturing, Raw } \\
\text { materials/mining } \mid \mathrm{n}=1\end{array}$ & More than $10,000 \mid n=23$ & 5 bn to 10 bn $€ \mid n=6$ & \\
\hline Others $\mid \mathrm{n}=4$ & & Above 10 bn $€ \mid \mathrm{n}=14$ & \\
\hline
\end{tabular}

To complete the survey, the participants were first asked to assess the importance of each barrier. The assessment was done on a 7-point Likert scale $(1=$ low to $7=$ high $)$. A barrier that has low importance (score $=1$ ) has negligible negative on efficient operations in European-Chinese logistics networks, whereas a very important barrier (score $=7$ ) has a significant negative impact on efficient operations in European-Chinese logistics networks. Afterwards, the strategies developed through the initial group exercise were assessed according to two distinct attributes (effectiveness and complexity) on a 7-point Likert scale $(1=$ low to $7=$ high). Effectiveness describes the impact of a strategy on overcoming the barrier. A strategy perceived as highly effective would have a major impact on the barrier to be overcome. The resources needed to implement this strategy were not considered for this attribute. Complexity describes the amount of resources that would be necessary to implement a certain strategy, with the assumption that a very complex implementation of a strategy will require more resources than an implementation that is not at all complex.

Finally, the survey participants were asked to assess all 14 development scenarios according to two distinct attributes, probability and vulnerability, on a 7 -point Likert scale $(1=$ low to $7=$ high). Probability here describes the likelihood of a scenario becoming a reality within the next 5 to 10 years. Vulnerability describes the positive, neutral, or negative impact of the scenario on efficient operations along BRI corridors if the scenario becomes a reality. For example, if the vulnerability of a certain scenario is low (score $=1$ ), this means that operations along the BRI would become less vulnerable (e.g., fewer supply chain disruptions) if this scenario were to become a reality. If the vulnerability is rated as high, this means that operations along the BRI would become more vulnerable (e.g., more supply chain disruptions) if this scenario were to become a reality. A neutral score $(=4)$ implies that the vulnerability of operations would not necessarily change, positively or negatively, in comparison with the status quo, if the scenario described were to become a reality. 


\section{Results}

The goal of this study was to outline the current barriers that companies face when operating along BRI corridors between Europe and China, as well as to provide indications for strategies that can assist in overcoming those barriers. Due to vagueness about how the initiative will develop in the future and the impact of those developments on European-Chinese logistics networks, the study additionally aimed to outline future development scenarios of the BRI, so that practitioners could prepare for them. Therefore, a moderated on-site group exercise building on the NGT was conducted among 15 LSCM practitioners with broad expertise in LSCM in general and the BRI in particular. The exercise identified 17 major barriers that are inhibiting efficient operations along BRI paths and derived 20 strategies for dealing with the four barriers that were selected for further discussions. Moreover, 14 BRI development scenarios were developed through the group exercise. Afterwards, the barriers, strategies and development scenarios from the group exercise were assessed through an online survey among 52 LSCM practitioners.

\subsection{Current BRI Barriers}

Although the BRI is already providing opportunities for improved logistics between Europe and China, several barriers need to be overcome in order to leverage their full potential. Based on the practitioners' input, 17 major BRI barriers were identified and categorized in six main clusters (see Figure 2). Within the clusters, the barriers outlined are listed in order of decreasing importance, based on the assessment of all barriers through the online survey. The overall assessment of current BRI barriers is outlined in Figure 3.

\begin{tabular}{|c|c|c|}
\hline Rail transport barriers & Geopolitical barriers & Maritime transport barriers \\
\hline $\begin{array}{l}\text { Volatile prices for railway due to } \\
\text { volatile (and non-transparent) } \\
\text { subsidy system } \\
\text { - Capacity shortage of railway } \\
\text { infrastructure (terminals - e.g. } \\
\text { Brest/Malaszewicze - and } \\
\text { wagons/cars) } \\
\text { - Aging railway infrastructure } \\
\text { - Volatile transportation times on } \\
\text { railway } \\
\text { - Damage of goods on the railway }\end{array}$ & $\begin{array}{l}\text { - Chinese protectionism (e.g. only } \\
\text { Chinese companies are allowed to } \\
\text { participate in tendering for } \\
\text { infrastructure) } \\
\text { - Missing harmonization of } \\
\text { European and Chinese activities } \\
\text { - Financial and political dependence } \\
\text { of some countries } \\
\text { - Missing local acceptance for more } \\
\text { transport }\end{array}$ & $\begin{array}{l}\text { Over capacities in sea freight } \\
\text { influence international logistics } \\
\text { networks } \\
\text { - Unclear influence of southern } \\
\text { European seaports on European- } \\
\text { Chinese logistics networks }\end{array}$ \\
\hline Regulatory barriers & Internal barriers & Informational barriers \\
\hline $\begin{array}{l}\text { - Missing harmonization of customs } \\
\text { - Non-transparent laws and } \\
\text { regulations }\end{array}$ & $\begin{array}{l}\text { Long-term planning difficult to } \\
\text { achieve (e.g. regarding } \\
\text { cooperation) } \\
\text { - Definition of own role regarding } \\
\text { the BRI (from a focal firm } \\
\text { perspective) }\end{array}$ & $\begin{array}{l}\text { - Data protection/data security } \\
\text { - Tracking and tracing along the rail } \\
\text { track }\end{array}$ \\
\hline
\end{tabular}

Figure 2. Overview of barriers of the Belt and Road Initiative (BRI). 


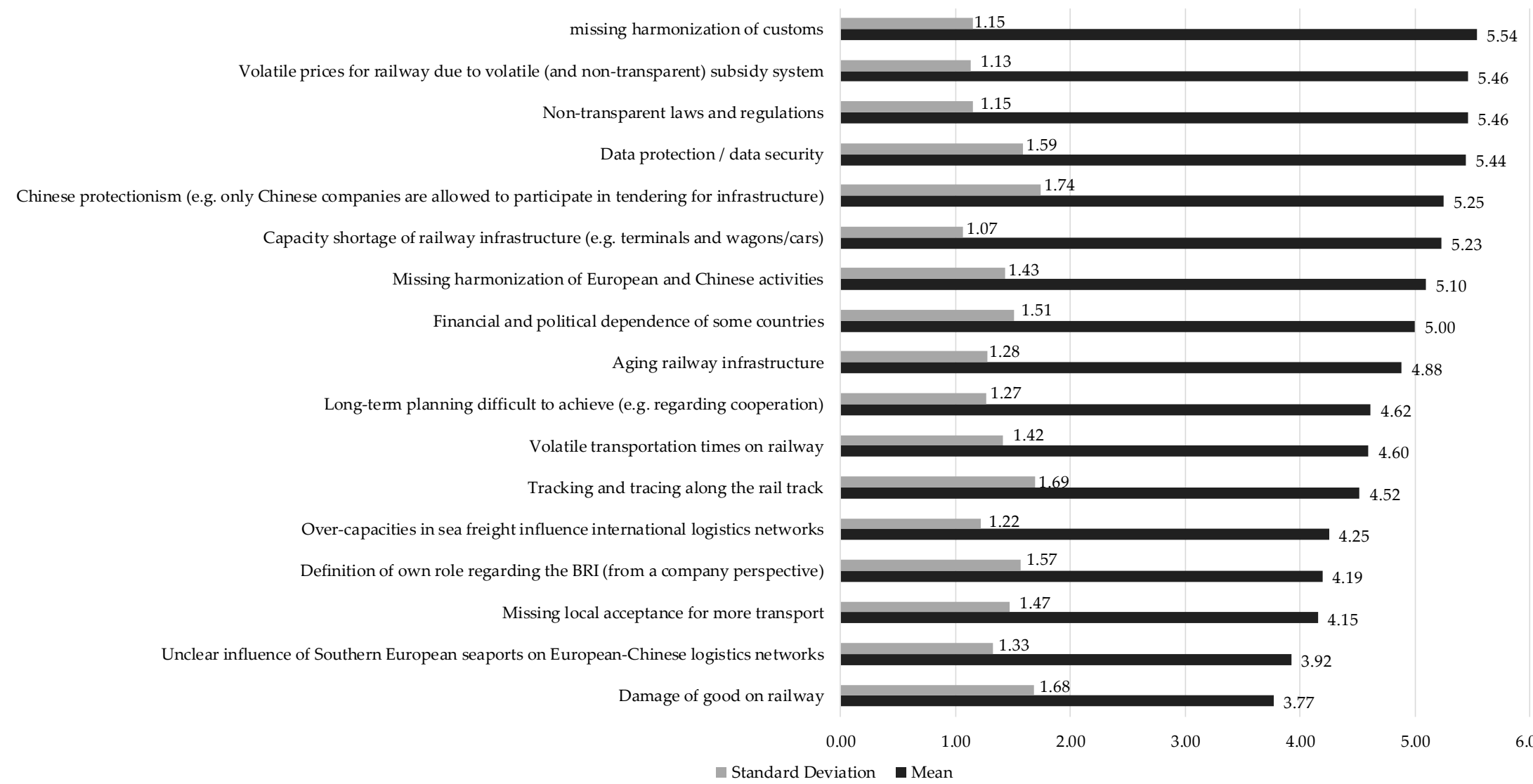

Figure 3. Industry assessment of importance of BRI barriers. 
Rail transport barriers: Over the past five years, rail cargo volumes between Europe and China have increased significantly, thus making rail a viable alternative to well-established sea freight, which has longer transportation times but a lower cost, or air freight, which traditionally involves a higher cost [56]. However, the practitioners assessed volatile prices for railway due to volatile (and non-transparent) subsidy system as the second most important of the 17 barriers (see Figure 3). According to them, the Chinese government heavily subsidizes rail transportation between China and Europe to increase demand for this transport mode. However, the subsidies are distributed at each quarter to China's domestic railway terminals. This is highly volatile and tends to be unpredictable for practitioners, as transport from a particular Chinese terminal to a European terminal may be low cost in one quarter but disproportionately expensive in the next, thus leading to the re-routing of China's domestic transport flow. This is particularly challenging for logistics service providers and their customers, as one of the participants explained, with everyone's agreement:

Our clients are used to having fixed prices for certain transport routes and volumes. In the case of rail transportation between China and Germany we are struggling to provide fixed prices since the subsidies for Chinese rail terminals are changing constantly. Once we establish a profitable and stable connection we have to change the domestic terminal to remain profitable, which leads to problems for our logistics planning on a regular basis. However, without the Chinese subsidies, the demand for rail transportation would be much lower than it is today.

Potential customers explained that, from their point of view, logistics service providers can provide them with fixed prices but only by pricing in the risk on their side, which makes these prices barely competitive. In addition, capacity shortage of railway infrastructure (terminals and wagons/cars) is among the more important BRI barriers. Owing to the different railway gauges in China, Europe, and the former Soviet Union, containers have to be transferred at dedicated terminals. This is currently causing a bottleneck on the border between Poland and Belarus (Malaszewicze/Brest). Although there are, depending on the EC used, different terminals available on the Chinese side, regardless of the EC taken, most rail transport to Europe has to pass through the Malaszewicze/Brest terminal, where containers often have to wait for four days or longer.

The infrastructure is not being expanded as fast as the demand for this mode of transport is increasing, and it is therefore becoming increasingly overloaded. This has led to increasing rail transport times between China and Europe because of high demand that is unaligned with the infrastructure capacity, as one participant underlined:

A few years ago, a train between Xi'an and Duisburg took around twelve days on average. Today, in 2019, this connection takes around 16 days, sometimes even more, which is mainly caused by the infrastructure bottleneck that we face at the Malaszewicze/Brest terminal.

This infrastructure capacity bottleneck is accompanied by a shortage of cars and wagons, also leading to delays of days at terminals before shipments can join a train. Due to the aforementioned infrastructure barriers and other issues, volatile transportation times on railways is also among the core current barriers to rail transportation between China and Europe. Customers and their service providers are often uncertain of when goods will arrive. The increase in transport times is manageable, according to the practitioners, but logistics planning is even more difficult when transport times are getting more and more volatile owing to unpredictable waiting times at important transport nodes. In addition, in some regions aging railway infrastructure remains a barrier, but it is improving owing to several BRI-related projects. Although damage of goods on the railway was named by the group as a potential BRI barrier, it had the lowest importance among the barriers assessed (see Figure 3).

Maritime transport barriers: According to the practitioners, the MSR provides fewer barriers compared with railway transportation. However, one barrier is overcapacities in sea freight impact international logistics networks, and practitioners are undecided as to how this will impact the BRI. As prices for sea freight between China and Europe are decreasing, this remains the dominant 
shipping option. Although, from a lead-time-perspective, rail transportation provides a viable option compared with sea freight, taking the cost perspective into account, rail transportation is struggling to compete. For logistics service providers and their customers, current sea freight prices impact their strategic assessment of BRI railway corridors, and they are undecided as to how new developments will impact future transportation routes. Additionally, the unclear influence of southern European seaports on European-Chinese logistics networks remains a barrier for companies operating along the BRI. The importance of this barrier is lower than others, but, with multiple Chinese investments in southern European seaports [40,41], logistics service providers have to investigate how this will impact on future transportation flows before investing accordingly.

Geopolitical barriers: Participants identified several geopolitical barriers throughout the group exercise that impact on the operations of, and strategic planning for, logistics networks. Chinese protectionism was rated as the most important barrier within this cluster. Company representatives participating in the group exercise concluded that, typically, only Chinese companies are involved in infrastructure projects along the BRI and foreign companies are prevented from participating in the tendering process. The same holds true for other stakeholders in the network, such as Chinese railway terminals, which are exclusively operated by Chinese companies, with no open tendering. Although this barrier was assessed as very important at the workshop conducted in September 2019, the Chinese president, Xi Jinping, directly addressed this issue in April 2019, when he invited more countries to participate in China's infrastructure projects. The continuing assessment of this barrier as important suggests that Western companies are still undecided as to whether this announcement represents a genuine effort to open up the initiative.

Second, missing harmonization of European and Chinese activities leads to a situation in which Western companies fear that the potential of the BRI cannot be leveraged. Participants unanimously agreed that the BRI can be beneficial for all stakeholders, but they fear that Europe is currently not taking an active role in the BRI, missing the opportunity to help create the foundation for future logistics networks. This is underlined by the statement of one participant:

Europe and China are the most important trade partners regarding the Belt and Road Initiative but are not working together as closely as necessary. If everything is done correctly, the initiative can be a win-win situation for all countries and stakeholders involved since it facilitates trade and consequently economic development. But currently, it seems to me that Europe does not have a unified voice to talk to China and to set up joint actions.

Third, participants stated that the risk of financial and political dependence of some countries remains a barrier, as China provides many of the countries along the BRI with the cash with which to finance infrastructure and other projects. Companies fear that less stable countries could fall into financial difficulties from which they would struggle to recover, directly impacting international supply chains in those regions. Fourth, most of the supply-chain-related BRI projects involve increased transport, but companies operating on the BRI experience missing local acceptance for more transport. This can lead to strikes and protests, giving rise to supply chain disruptions and delayed projects.

Regulatory barriers: Missing harmonization of customs was ranked as the most important BRI barrier (see Figure 3). Specifically, participants stated that customs clearance for importing goods from China to Europe is not harmonized and is handled differently in different European countries. This is challenging, as goods and customs declarations are interpreted differently in different European countries. For goods entering China, customs clearance still remains one of the major sources of supply chain disruption. Therefore, the group unanimously agreed that inconsistent customs processes between China and Europe form one of the major barriers preventing the success of the BRI. This is in line with current research in this field that has concluded that trade facilitation can positively impact the success of the BRI $[57,58]$. Closely connected to this and also among the most important barriers are non-transparent laws and regulations. Companies with logistics operations between Europe and China struggle to adapt their operations to constantly changing laws and regulation, mainly induced, 
from their point of view, by the Chinese side. This includes not only customs regulations, but also safety regulations and rules for transporting goods via rail.

Internal barriers: These include barriers that a focal firm faces when operating on BRI routes between China and Europe. Owing to the volatile nature of the BRI, companies experience the barrier that long-term planning is difficult to achieve, especially when it comes to finding long-term partners with which to set up logistics networks. Owing to the circumstances described when discussing rail transportation barriers, with networks regularly changing, logistics service providers expend more effort in constantly adjusting their networks than in establishing long-term cooperation with terminal operators. In addition, definition of own role regarding the BRI (from a focal firm perspective) was identified as a BRI barrier, although its importance is relatively low. Logistics service providers stated that they do not yet know what their role in the BRI will be, regarding their active involvement and future possibilities, if China reduces protectionism (e.g., becoming terminal operators or actively investing in infrastructure). This indecisiveness is based on the volatile nature and uncertain future of BRI developments from a focal firm perspective.

Informational barriers: According to the practitioners, data protection/data security is among the most important barriers regarding the BRI. Participants fear that the data they have to divulge in order to transport goods across a multitude of countries, especially when considering transporting goods by rail, could be misused. Although they have no concrete evidence that their particular data has been misused in the past, they have trust issues when it comes to data sharing with partners from foreign countries. Researchers in this field have shown that, in the case of China, government support can increase trust in data sharing, but it is also up to the cooperating companies to gain guanxi (China's unique form of interpersonal relationships) in order to gain trust and facilitate data sharing [59]. In addition, tracking and tracing along the rail track remains an issue. This barrier was placed in this cluster owing to its informational nature, although it also belongs with the rail-transport-related barriers. Company representatives stressed that, for large parts of the rail route, especially entering and leaving Russia, they do not know exactly where their containers are. Without information on location and expected waiting times along the track, forecasting arrival times becomes even more challenging.

\subsection{Strategies to Leverage the Potentials of the BRI}

Through the NGT among 15 LSC professionals, strategies for four BRI barriers were synthesized. Four BRI barriers-missing harmonization of customs, volatile prices for railway due to volatile (and non-transparent) subsidy system, capacity shortage of railway infrastructure (e.g., terminals and wagons/cars), and tracking and tracing along the rail track-were chosen by the group of 15 LSCM professionals for strategy development (the second phase of NGT, problem solution) and a total set of 20 strategies was proposed. Subsequently, all of the strategies were assessed according to their effectiveness (impact on the barrier being resolved) and complexity (amount of resources necessary to implement the strategy) through a subsequent questionnaire completed by 52 LSCM professionals. The results can be seen in Table 3 . 
Table 3. Strategies for dealing with BRI barriers.

\begin{tabular}{|c|c|c|c|c|c|}
\hline BRI Barrier & Strategy & Effectiveness & SD Effectiveness & Complexity & SD Complexity \\
\hline \multirow{3}{*}{$\begin{array}{c}\text { Missing } \\
\text { harmonization of } \\
\text { customs }\end{array}$} & Digitalization of customs clearance process & 6.19 & 0.90 & 5.79 & 1.23 \\
\hline & Establishment of EU-wide standards for interpretation of goods & 5.67 & 1.17 & 5.48 & 1.37 \\
\hline & Creation of political associations to draw attention to the topic by lobbying & 4.60 & 1.40 & 4.87 & 1.40 \\
\hline \multirow{4}{*}{$\begin{array}{l}\text { Volatile prices for } \\
\text { railway due to } \\
\text { volatile (and } \\
\text { non-transparent) } \\
\text { subsidy system }\end{array}$} & $\begin{array}{c}\text { Block space agreements: customer, service providers and Chinese provinces agree } \\
\text { on volumes for a longer period and a fixed price }\end{array}$ & 5.42 & 1.12 & 4.83 & 1.41 \\
\hline & $\begin{array}{c}\text { (Cross-industry) cooperation of multiple customers to consolidate volumes for } \\
\text { more bargaining power for stable prices }\end{array}$ & 4.58 & 1.41 & 4.85 & 1.34 \\
\hline & $\begin{array}{l}\text { Establish cross-industry lobby organization to show China that volatile prices } \\
\text { keep customers from using the railway }\end{array}$ & 4.29 & 1.72 & 4.48 & 1.32 \\
\hline & Buy insurance to cover price volatility & 4.19 & 1.51 & 4.62 & 1.61 \\
\hline \multirow{9}{*}{$\begin{array}{c}\text { Capacity shortage } \\
\text { of railway } \\
\text { infrastructure } \\
\text { (e.g., terminals and } \\
\text { wagons/cars) }\end{array}$} & $\begin{array}{l}\text { Digitalized and standardized documents along the track to avoid waiting trains } \\
\text { due to incorrect documents }\end{array}$ & 5.94 & 1.10 & 4.96 & 1.56 \\
\hline & Upgrading of more double track sections to avoid waiting trains & 5.58 & 1.17 & 5.15 & 1.34 \\
\hline & $\begin{array}{l}\text { Increased transparency on current and expected capacity bottlenecks and planned } \\
\text { construction works as well as impact on transit times }\end{array}$ & 5.42 & 1.23 & 4.35 & 1.43 \\
\hline & $\begin{array}{l}\text { Having infrastructure expansion financed directly by European companies } \\
\text { instead of waiting for government action }\end{array}$ & 5.10 & 1.30 & 5.44 & 1.31 \\
\hline & More optimized, coordinated timetables of trains & 5.08 & 1.43 & 4.44 & 1.63 \\
\hline & Additional cross-border terminals around Brest/Malaszewicze & 4.94 & 1.39 & 4.48 & 1.20 \\
\hline & $\begin{array}{l}\text { Cross-industry cooperation through a neutral, third-party authority that creates } \\
\text { synthesized transparency on customer orders and schedules them accordingly }\end{array}$ & 4.94 & 1.36 & 4.88 & 1.37 \\
\hline & Establishment of giga-cargo trains on the main tracks in the former Soviet Union & 4.81 & 1.66 & 4.75 & 1.53 \\
\hline & Creation of political associations to draw attention to the topic by lobbying & 4.23 & 1.35 & 4.63 & 1.47 \\
\hline \multirow{4}{*}{$\begin{array}{l}\text { Tracking and } \\
\text { tracing along the } \\
\text { rail track }\end{array}$} & Logistics service providers put GPS trackers on containers by themselves & 5.69 & 1.20 & 3.40 & 1.73 \\
\hline & Implementation of a tracking system, similar to the one for ships, for trains & 5.63 & 1.11 & 4.29 & 1.31 \\
\hline & Establishment of data standards to regularly report train/container locations & 5.42 & 1.10 & 5.10 & 1.29 \\
\hline & $\begin{array}{l}\text { Increase funding for further development and deployment of smart } \\
\text { interconnected train infrastructure }\end{array}$ & 5.02 & 1.22 & 5.06 & 1.25 \\
\hline
\end{tabular}


In general, during the practitioner discussions it became obvious that dealing with many of the BRI barriers requires governmental support from either the European or Chinese side, or both. Therefore, companies participating in the group exercise were unable to tackle the barriers alone and often had to react to changes rather than proactively addressing them.

This is especially true for one of the most important BRI barriers that was discussed. Although the group managed to synthesize some strategies to manage issues regarding the missing harmonization of customs, they clearly expressed the need for more government support, as they are directly affected by customs procedures but have little influence on simplifying them. However, for unifying EU-wide standards for customs clearance, government authorities should collaborate to ensure the practicability of the processes and rules developed. In conjunction with this, the digitalization of customs clearance processes on both sides would improve logistics efficiency for trading goods between Europe and China, although the group agreed that this would be highly complex.

For dealing with volatile prices, some logistics service providers outlined that they are working on block space agreements with their customers and the Chinese provinces to agree fixed volumes and prices for longer than the typical quarter. Although this strategy has been very effective, implementing it is complex, and customers must have very high volumes. Practitioners also stressed the importance for cross-industry cooperation of consolidating volumes to increase bargaining power for more stable prices. Other possible, but less effective strategies include insurances to cover price volatility or the formal lobbying of the Chinese government.

To manage the capacity shortage of railway infrastructure, different approaches have been developed that either utilize the existing capacity more efficiently or call for additional infrastructure to relieve current bottlenecks. The utilization of existing capacities, as well as the upgrading of additional capacities, was assessed as being effective but equally complex. To utilize the existing capacity more efficiently, digitalized and standardized documents can assist clearance processes at specific nodes to reduce waiting times. Digitalization could also assist in creating more transparency on expected bottlenecks and construction works, and their impact on expected transit times. Without this transparency, companies are unable to react promptly. Digitalization can also assist in scheduling order fulfillment according to expected bottlenecks and transit times. However, with increasing demand for rail transportation along the BRI, more efficient capacity utilization will not be enough, and either governments or private actors must invest in physical infrastructure. More precisely, more double track sections and additional cross-border terminals must be built to relieve the current bottleneck at Brest/Malaszewicze. Indeed, the call for railway infrastructure expansion is in line with existing studies. Lobyrev et al. [45] also suggest more infrastructure investments at the Poland-Belarus-border, since railway volume is increasing but the terminal cannot cope with the increasing demand. Moreover, they propose additional backup/backbone terminals and other measures to improve railway performance. Zhao et al. also stress that existing railway capacities have to be managed more efficiently and propose cargo consolidation centers before cargo is supplied to the terminals in order to facilitate a more efficient flow of goods to the domestic terminals in China [43].

To manage tracking and tracing along the rail track, most logistics service providers offer a container GPS tracking service, a widely used, relatively simple, and effective strategy. However, data protocols and tracking systems are not standardized, so every logistics service provider has to develop its own solution. Moreover, even if the location of goods is made visible, waiting times at infrastructure nodes and construction works remain unpredictable.

\subsection{Future Development Paths of the BRI}

Following the procedure outlined in Section 3, 14 BRI development scenarios have been proposed and assessed through the follow-up survey. Table 4 outlines the scenarios developed as well as the overall results of the assessment, sorted by descending probability. 
Table 4. Overview of BRI scenario assessment by probability and vulnerability.

\begin{tabular}{|c|c|c|c|c|c|}
\hline$\#$ & Scenario & $\begin{array}{l}\text { Probability } \\
\text { (Mean) }\end{array}$ & SD Probability & $\begin{array}{l}\text { Vulnerability } \\
\text { (Mean) }\end{array}$ & $\begin{array}{c}\text { SD } \\
\text { Vulnerability }\end{array}$ \\
\hline 1 & $\begin{array}{l}\text { China's protectionism } \\
\text { increases and Europe's } \\
\text { dependence on China } \\
\text { increases }\end{array}$ & 4.94 & 1.13 & 4.77 & 1.42 \\
\hline 2 & $\begin{array}{l}\text { Owing to the BRI, industrial } \\
\text { production of Eastern } \\
\text { Europe moves further east } \\
\text { (industrial center of gravity } \\
\text { moves east) }\end{array}$ & 4.81 & 1.18 & 4.25 & 1.19 \\
\hline 3 & $\begin{array}{c}\text { Significant sea freight } \\
\text { volume from China to } \\
\text { Europe will be handled via } \\
\text { southern European seaports }\end{array}$ & 4.38 & 1.39 & 4.06 & 1.17 \\
\hline 4 & $\begin{array}{l}\text { Dobrá establishes itself in } \\
\text { the long term as a strong } \\
\text { intermodal terminal to } \\
\text { relieve Brest/Malaszewicze }\end{array}$ & 4.23 & 1.12 & 3.37 & 1.04 \\
\hline 5 & $\begin{array}{c}\text { Transport by rail from China } \\
\text { to Europe will become a } \\
\text { strong competitor to sea } \\
\text { freight }\end{array}$ & 4.10 & 1.78 & 3.71 & 1.63 \\
\hline 6 & $\begin{array}{c}\text { The Northern Sea Route will } \\
\text { be established as a viable } \\
\text { option for sea freight } \\
\text { between China and Europe }\end{array}$ & 4.06 & 1.46 & 3.87 & 1.39 \\
\hline 7 & $\begin{array}{c}\text { Import customs clearance to } \\
\text { Europe is carried out } \\
\text { according to a uniform } \\
\text { standard }\end{array}$ & 4.04 & 1.47 & 3.06 & 1.32 \\
\hline 8 & $\begin{array}{c}\text { China and Europe get closer } \\
\text { to each other and develop a } \\
\text { common strategy regarding } \\
\text { the BRI }\end{array}$ & 3.96 & 1.56 & 3.62 & 1.76 \\
\hline 9 & $\begin{array}{l}\text { IT standards for data } \\
\text { exchange among all partners } \\
\text { will be established }\end{array}$ & 3.88 & 1.64 & 3.62 & 1.61 \\
\hline 10 & $\begin{array}{l}\text { China reduces subsidies } \\
\text { drastically for railway }\end{array}$ & 3.69 & 1.60 & 4.71 & 1.57 \\
\hline 11 & $\begin{array}{c}\text { The United States of } \\
\text { America is increasingly } \\
\text { isolated from world trade by } \\
\text { the BRI }\end{array}$ & 3.69 & 1.45 & 3.98 & 1.25 \\
\hline 12 & $\begin{array}{l}\text { China and Europe reach a } \\
\text { free-trade agreement }\end{array}$ & 3.62 & 1.60 & 3.37 & 1.68 \\
\hline 13 & $\begin{array}{l}\text { Europe develops a unified } \\
\text { strategy for how to respond } \\
\text { to the BRI }\end{array}$ & 3.33 & 1.55 & 3.54 & 1.38 \\
\hline 14 & $\begin{array}{l}\text { New transport technologies, } \\
\text { e.g., Hyperloop, UAVs, and } \\
\text { AGVs, will disrupt the } \\
\text { logistics industry and make } \\
\text { the rail connection obsolete }\end{array}$ & 2.58 & 1.47 & 3.79 & 1.64 \\
\hline
\end{tabular}


Figure 4 provides a graphical representation of the BRI scenario portfolio classified into four different BRI scenario clusters (monitor, prepare, propel, exploit). Although the lines between those clusters are not as narrow as displayed, the clusters aim to provide guidance to practitioners on how to deal with those scenarios. Scenarios in the monitor cluster are less likely to become reality but would increase the vulnerability of European-Chinese logistics networks. Therefore, companies have to observe their development closely to track whether they become more probable. Scenarios in the prepare cluster are more likely to become reality in the near future and may lead to increased vulnerability. Therefore, companies need to prepare proactively for them and develop strategies that take these scenarios into account. The propel cluster includes scenarios for less vulnerable, though less probable, logistics networks between Europe and China. Scenarios in the exploit cluster must be utilized in a beneficial way, since they are more likely to occur and can decrease the vulnerability of European-Chinese logistics networks.

Analyzing Figure 4, it is obvious that most scenarios do not dramatically impact the vulnerability of European-Chinese logistics networks. This could indicate that the participants are unsure about the scenarios' impact on vulnerability; however, the probabilities of the scenarios are diverse and provide a valuable guide for practice. The practitioners believe that, owing to the BRI, the resulting logistics connection of Eurasian countries and their corresponding economic development and industrial production could move far eastward from Europe. In addition, practitioners from Central Europe expect that China's protectionism will increase and participation in tendering processes will only be possible for Chinese firms, despite China's expressed willingness to open up. Moreover, European companies need to prepare for, or at least analyze the possibility of, a volume shift from northern to southern European seaports. This could lead to a need for service providers to build their competence and capacity in the southern European region. This scenario does not predict how much volume will shift, and it does not necessarily imply that northern European seaports will lose importance. However, it is a scenario that companies operating in European-Chinese logistics networks should consider and prepare for.

Participants identified the current cross-border railway terminal at Malaszewicze/Brest as a major bottleneck for rail transportation and asserted that the development of Dobrá (Slovakia) as an additional terminal could relieve this situation. This scenario is in the exploit cluster, as it was assessed as more likely to become reality, and would decrease the vulnerability of current logistics networks. Moreover, LSCM practitioners think that it is more likely that railway transport between Europe and China will become a strong competitor over sea freight in the near future. Nevertheless, this does not necessarily mean that this transportation mode is about to take over the sea freight volume completely. Since the volume currently transported via rail is much lower than the sea freight volume, it is more likely that becoming a competitor in this case means that rail transportation will develop into a reliable second option after sea freight and will be more implemented by practitioners as a result of it. The scenario in which the import customs clearance to Europe is carried out with uniform standards has been assessed as the scenario with the highest positive impact on the vulnerability of European-Chinese logistics networks, meaning that less disruptions would occur if this scenario becomes reality. This is underlined by the previous finding that the BRI challenge of missing harmonization of customs has been assessed as the most significant barrier (see Figure 3) in the path to enable more efficient operations along the BRI corridors. The practitioners participating in the assessment are also undecided as to whether China and Europe should get closer to each other and develop a common strategy regarding the BRI, or whether IT standards for data exchange among the involved parties will be established, although both scenarios would slightly decrease the vulnerability. Moreover, it is viewed as more unlikely that the United States will be increasingly isolated from world trade due to better trade connections between Asia, Europe and Africa generated through the BRI. One of the scenarios clearly placed in the monitor cluster is that China will drastically reduce subsidies for the rail route within the next five to ten years. BRI has been clearly positioned as one of China's major long-term strategies, so it seems unlikely that support for rail connections will decrease. 


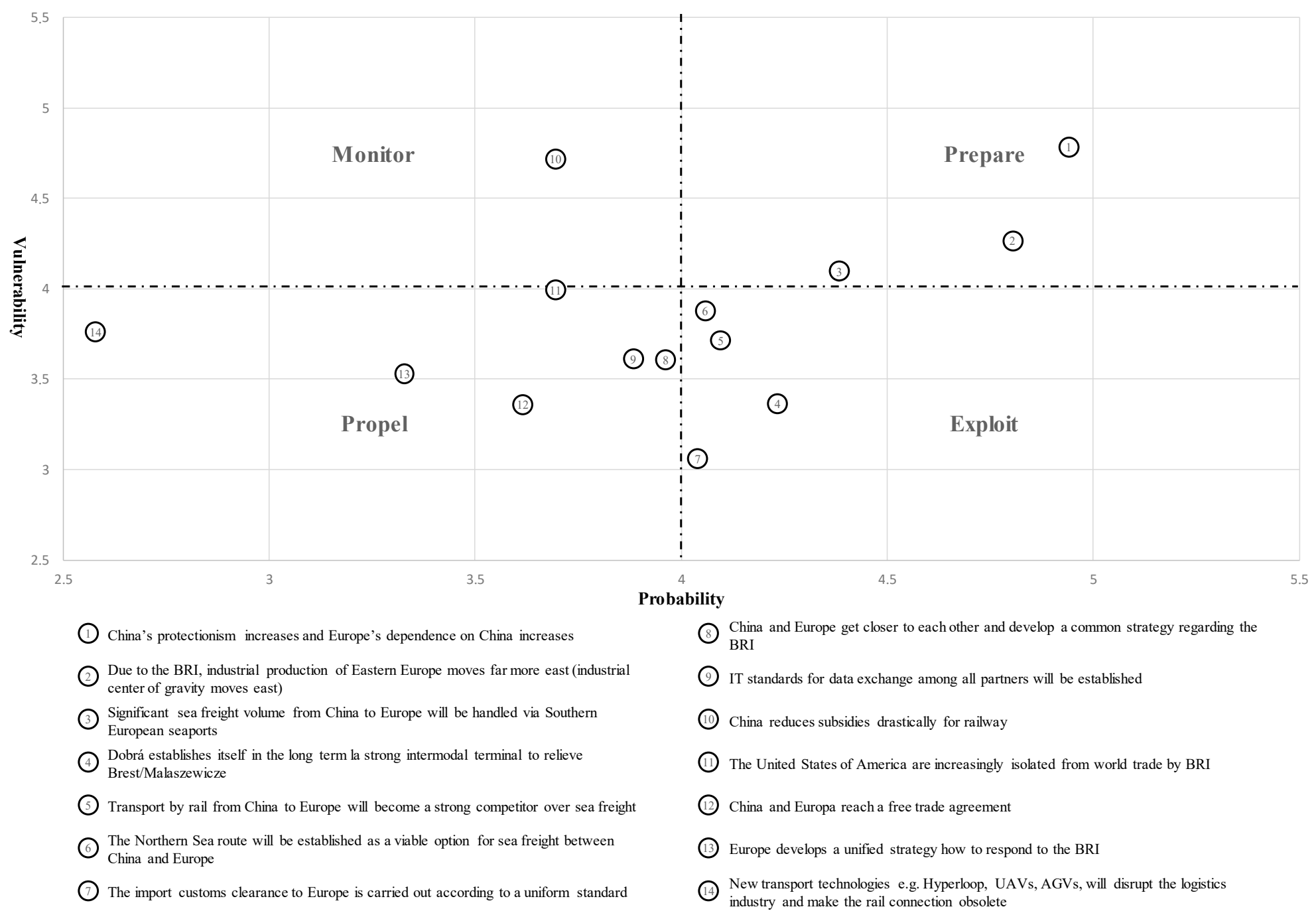

Figure 4. Graphic representation of the BRI scenario portfolio by probability vs. vulnerability. 
Two scenarios are clearly placed in the propel cluster, meaning that those scenarios may be unlikely, but their realization should be forced from an LSCM perspective, since their becoming reality would generate more efficient operations with fewer disruptions along the paths between Europe and China. First, a free trade agreement between Europe and China would decrease the vulnerability of networks between those regions and would be beneficial for LSCM. Second, a unified European strategy on how to respond to the BRI has been assessed as beneficial from an LSCM perspective, but is even less likely than the aforementioned scenario of a free trade agreement. Lastly, the scenario that new technologies such as Hyperloops of automatically guided vehicles will make the rail connection obsolete has been assessed as highly unlikely.

\section{Implications}

By systematically synthesizing LSCM practitioners' knowledge on the BRI through a moderated on-site group exercise among 15 LSCM professionals building on the NGT, followed by a post-assessment through an online questionnaire among 52 LSC practitioners, the study outlined a coherent picture of the current barriers and development paths of the BRI from an LSCM perspective and provided strategies for dealing with important barriers. Specifically, 17 barriers that inhibit efficient operations within European-Chinese logistics networks were identified and their importance assessed. Those barriers are gathered into the clusters rail transport barriers, maritime transport barriers, geopolitical barriers, regulatory barriers, internal barriers, and informational barriers, based on which the group derived 20 strategies for dealing with important barriers, that were subsequently assessed by the group of 52 LSCM professionals according to each strategy's effectiveness and complexity. Moreover, 14 conceivable development scenarios for the BRI have been proposed through the group exercise and assessed according to their probability and impact on the vulnerability of European-Chinese logistics networks through the follow-up online questionnaire. This study is therefore the first of its kind seeking to outline current barriers and development paths of the BRI from a LSCM perspective and attempting to close the gap between research and practice in this field, thereby contributing to both sides equally.

For LSCM research, the study provides a holistic overview of current BRI barriers. This will allow researchers to better understand the current problems and needs of practice and align research activities accordingly to contribute to addressing existing problems. Although this study cannot seek to overcome all the barriers identified, it can contribute to the discussion and propose, among other measures, capacity utilization schemes for rail transportation, utilization of artificial intelligence algorithms for arrival forecasting, or assessing optimal network configurations to relieve current infrastructure bottlenecks. Moreover, owing to the vague and unpredictable nature of the BRI and its projects, this study can contribute to a more comprehensive understanding by calling on researchers to conduct more in-depth scenario analysis than has been possible here. This study must be understood as only the starting point.

For practice, the study seeks to provide a more comprehensive understanding of the BRI and its implications from an LSCM perspective. Although leaving their refinement to practice, the strategies suggested for dealing with important BRI barriers suggest valid future directions for dealing with them. However, the group discussions and results also indicate that most of the present BRI barriers that companies operating in European-Chinese logistics networks face can only be overcome with government support, either from the European or the Chinese side. Therefore, this study can assist government actors in better understanding the needs of practice. However, before implementing countermeasures at a government level, further, closer discussions between government stakeholders and companies are necessary.

Moreover, it must be acknowledged that the study is the first of its kind that has sought to contribute to the analysis of the future development of the BRI and its impact on LSCM. By developing 14 conceivable scenarios and assessing them in terms of probability and vulnerability, the group has provided practitioners with a first indication of possible future developments. Through the classification into monitor, prepare, propel, and exploit scenarios, practitioners have been provided with 
a guide for dealing with these scenarios, although it is acknowledged that their development needs closer investigation.

Furthermore, throughout the group exercise, it became obvious that, for rail transportation in particular, the state of development regarding digital technologies is low, but further digitalization could lead to more efficient operations along the track. To improve this, not only researchers and practitioners, but also governmental institutions, could work together to develop digital tools and solutions, thus improving the efficiency of the rail silk road. However, this must go hand-in-hand with physical infrastructure expansion to leverage the full potential of the BRI with regard to rail transport.

\section{Final Remarks}

Although this study is the first of its kind that has sought to outline a comprehensive picture of the BRI from an LSCM perspective, by synthesizing the current BRI barriers, providing possible strategies to overcome these barriers, and outlining possible future development scenarios for the BRI, no study is without limitations.

First, the BRI aims to facilitate more efficient trade between Europe, China, and Africa by improving infrastructure at different levels. However, this study focused only on BRI barriers and developments between Europe and China, and excluded Africa from the discussion. However, that continent is fundamental to the overall initiative, and China is investing heavily in improving infrastructure in several African countries. Nevertheless, the European-Chinese trade relationship remains one of the most important in the world and is key to the overall success of the BRI. To derive more focused results, the study limited the group exercise to European-Chinese logistics networks, but investigating the BRI's implications for African countries is still a necessary task for future researchers.

Second, the LSCM professionals participating in the NGT group exercise were all employed in Western European companies, mostly of German origin. Although some of the individual participants were of Chinese origin, no Chinese company took part in the exercise. Thus, it can be concluded that the set of practitioners is likely to have expressed a European point of view on the BRI. Nevertheless, all participants had close connections to Chinese companies and the Chinese market, and their long experience in the field of European-Chinese logistics networks can be considered valuable. Additionally, no participant from a public authority or governmental institution was included in the NGT group exercise, which can account for bias, since their perspective was not considered. However, one participant of the NGT group exercise was from an LSCM association that seeks to bridge the gap between industry and governments. Nevertheless, considering both perspectives in a more even compilation of the group might have been insightful as well.

Third, from a methodological point of view, the limited sample size (15 professionals), though sufficient to synthesize the experts' knowledge through the NGT, a proven method for extracting LSCM practitioners' knowledge in a certain field, nevertheless prevents the study from drawing more fine-grained conclusions. In particular, the assessments of barriers, strategies, and development scenarios through the follow-up survey among 52 LSCM professionals should be understood as a first indication regarding specific developments, rather than an in-depth quantitative study. Nevertheless, the assessments provide a condensed opinion of LSCM professionals with longstanding experience in their field and can therefore be beneficial for other practitioners.

In summary, this study should be understood as a call for further research on the BRI and its implications for LSCM. For all the areas covered by this study, further quantitative research is necessary to provide more precise results. However, the study is the first of its kind to aim specifically at identifying current barriers resulting from the BRI from an LSCM perspective and outlining future development scenarios for an initiative that will be of great importance for companies operating in international logistics networks. 
Funding: This research was funded by the Kuehne Foundation, Dorfstr. 80, 8834 Schindellegi, Switzerland.

Acknowledgments: The authors would like to thank the Kuehne Foundation for the financial support of this research project.

Conflicts of Interest: The author declares no conflict of interest.

\section{References}

1. Liu, X. The Silk Road in World History; New Oxford World History; Oxford University Press: New York, NY, USA, 2010; ISBN 978-0-19-516174-8.

2. Ferdinand, P. Westward ho-the China dream and 'one belt, one road': Chinese foreign policy under Xi Jinping. Int. Aff. 2016, 92, 941-957. [CrossRef]

3. Cai, P. Understanding China's Belt and Road Initiative; Lowy Institute for International Policy: Sydney, Australia, 2017.

4. Huang, Y. Understanding China's Belt \& Road Initiative: Motivation, framework and assessment. China Econ. Rev. 2016, 40, 314-321. [CrossRef]

5. Flint, C.; Zhu, C. The geopolitics of connectivity, cooperation, and hegemonic competition: The Belt and Road Initiative. Geoforum 2019, 99, 95-101. [CrossRef]

6. Yu, H. Motivation behind China's 'One Belt, One Road' Initiatives and Establishment of the Asian Infrastructure Investment Bank. J. Contemp. China 2016, 26, 353-368. [CrossRef]

7. ZiroMwatela, R.; Changfeng, Z. Africa in China's 'One Belt, One Road' Initiative: A Critical Analysis. IOSR J. Humanit. Soc. Sci. 2016, 21, 10-21.

8. Ehizuelen, M.M.O. More African countries on the route: The positive and negative impacts of the Belt and Road Initiative. Transnatl. Corp. Rev. 2017, 9, 341-359. [CrossRef]

9. Shah, A. Building a Sustainable Belt and Road. Horizons 2016, 7, 212-222.

10. Feng, T.-T.; Kang, Q.; Pan, B.-B.; Yang, Y.-S. Synergies of sustainable development goals between China and countries along the Belt and Road initiative. Curr. Opin. Environ. Sustain. 2019, 39, 167-186. [CrossRef]

11. Guo, H.; Liu, J.; Qiu, Y.; Menenti, M.; Chen, F.; Uhlir, P.F.; Zhang, L.; Van Genderen, J.; Liang, D.; Natarajan, I.; et al. The Digital Belt and Road program in support of regional sustainability. Int. J. Digit. Earth 2018, 11, 657-669. [CrossRef]

12. Xiao, H.; Cheng, J.; Wang, X. Does the Belt and Road Initiative Promote Sustainable Development? Evidence from Countries along the Belt and Road. Sustainability 2018, 10, 4370. [CrossRef]

13. Yu, C.; Zhang, R.; An, L.; Yu, Z. Has China's Belt and Road Initiative Intensified Bilateral Trade Links between China and the Involved Countries? Sustainability 2020, 12, 6747. [CrossRef]

14. Gu, J.; Corbett, H.; Leach, M. Introduction: The Belt and Road Initiative and the Sustainable Development Goals: Opportunities and Challenges. IDS Bull. 2019, 50, 50. [CrossRef]

15. Enderwick, P. The economic growth and development effects of China's One Belt, One Road Initiative. Strat. Chang. 2018, 27, 447-454. [CrossRef]

16. Ascensão, F.; Fahrig, L.; Clevenger, A.P.; Corlett, R.T.; Jaeger, J.A.G.; Laurance, W.F.; Pereira, H.M. Environmental challenges for the Belt and Road Initiative. Nat. Sustain. 2018, 1, 206-209. [CrossRef]

17. Chan, S. The Belt and Road Initiative: Implications for China and East Asian Economies. Cph. J. Asian Stud. 2018, 35, 52-78. [CrossRef]

18. Du, J.; Zhang, Y. Does One Belt One Road initiative promote Chinese overseas direct investment? China Econ. Rev. 2018, 47, 189-205. [CrossRef]

19. Herrero, A.G.; Xu, J. China's Belt and Road Initiative: Can Europe Expect Trade Gains? China World Econ. 2017, 25, 84-99. [CrossRef]

20. Hurley, J.; Morris, S.; Portelance, G. Examining the debt implications of the Belt and Road Initiative from a policy perspective. J. Infrastruct. Policy Dev. 2019, 3, 139-175. [CrossRef]

21. Ming Hao, Z. The Belt and Road Initiative and its Implications for China-Europe Relations. Int. Spect. 2016, 51, 109-118. [CrossRef]

22. Li, K.X.; Jin, M.; Qi, G.; Shi, W.; Ng, A.K.Y. Logistics as a driving force for development under the Belt and Road Initiative-The Chinese model for developing countries. Transp. Rev. 2017, 38, 457-478. [CrossRef]

23. Lee, P.T.-W.; Hu, Z.-H.; Lee, S.-J.; Choi, K.-S.; Shin, S.-H. Research trends and agenda on the Belt and Road (B\&R) initiative with a focus on maritime transport. Marit. Policy Manag. 2017, 45, 282-300. [CrossRef] 
24. Liu, X.; Zhang, K.; Chen, B.; Zhou, J.; Miao, L. Analysis of logistics service supply chain for the One Belt and One Road initiative of China. Transp. Res. Part E Logist. Transp. Rev. 2018, 117, 23-39. [CrossRef]

25. Ye, J.; Haasis, H.-D. Impacts of the BRI on International Logistics Network. In Humanitarian Logistics and Sustainability; Springer Science and Business Media LLC: Berlin/Heidelberg, Germany, 2018; pp. 250-254.

26. Chan, H.K.; Dai, J.; Wang, X.; Lacka, E. Logistics and supply chain innovation in the context of the Belt and Road Initiative (BRI). Transp. Res. Part E Logist. Transp. Rev. 2019, 132, 51-56. [CrossRef]

27. Thürer, M.; Tomašević, I.; Stevenson, M.; Blome, C.; Melnyk, S.; Chan, H.K.; Huang, G.Q. A systematic review of China's belt and road initiative: Implications for global supply chain management. Int. J. Prod. Res. 2019, 58, 2436-2453. [CrossRef]

28. Aoyama, R. “One Belt, One Road”: China's New Global Strategy. J. Contemp. East Asia Stud. 2016, 5, 3-22. [CrossRef]

29. Guluzian, C. Making Inroads: China's New Silk Road Initiative. Cato J. 2017, 37, 135-147.

30. Hillman, J. China's Belt and Road Is Full of Holes; Center for Strategic \& International Studies: Washington, DC, USA, 2018.

31. Wang, H. China's Approach to the Belt and Road Initiative: Scope, Character and Sustainability. J. Int. Econ. Law 2019, 22, 29-55. [CrossRef]

32. Walking New Avenues in Management Research Methods and Theories: Bridging Micro and Macro Domains. J. Manag. 2011, 37, 395-403. [CrossRef]

33. Banks, G.C.; Pollack, J.M.; Bochantin, J.E.; Kirkman, B.L.; Whelpley, C.E.; O’Boyle, E.H. Management's Science-Practice Gap: A Grand Challenge for All Stakeholders. Acad. Manag. J. 2016, 59, 2205-2231. [CrossRef]

34. Hambrick, D.C. What if the Academy Actually Mattered? Acad. Manag. Rev. 1994, 19, 11-16. [CrossRef]

35. Kieser, A.; Nicolai, A.; Seidl, D. The Practical Relevance of Management Research: Turning the Debate on Relevance into a Rigorous Scientific Research Program. Acad. Manag. Ann. 2015, 9, 143-233. [CrossRef]

36. Delbecq, A.L.; Van De Ven, A.H. A Group Process Model for Problem Identification and Program Planning. J. Appl. Behav. Sci. 1971, 7, 466-492. [CrossRef]

37. Ellingsen, I.; Størksen, I.; Stephens, P. Q methodology in social work research. Int. J. Soc. Res. Methodol. 2010, 13, 395-409. [CrossRef]

38. Nitsche, B.; Durach, C.F. Much discussed, little conceptualized: Supply chain volatility. Int. J. Phys. Distrib. Logist. Manag. 2018, 48, 866-886. [CrossRef]

39. NDRC. Vision and Actions on Jointly Building Silk Road Economic Belt and 21st Century Maritime Silk Road; National Development and Reform Commission: Beijing, China, 2015.

40. Van der Putten, F.-P.; Meijnders, M. China, Europe and the Maritime Silk Road; The Netherlands Institute of International Relations Clingendael: The Hague, The Netherlands, 2015.

41. Yang, D.; Pan, K.; Wang, S. On service network improvement for shipping lines under the one belt one road initiative of China. Transp. Res. Part E Logist. Transp. Rev. 2018, 117, 82-95. [CrossRef]

42. Wen, X.; Ma, H.-L.; Choi, T.-M.; Sheu, J.-B. Impacts of the Belt and Road Initiative on the China-Europe trading route selections. Transp. Res. Part E Logist. Transp. Rev. 2019, 122, 581-604. [CrossRef]

43. Zhao, L.; Zhao, Y.; Hu, Q.; Li, H.; Stoeter, J. Evaluation of consolidation center cargo capacity and loctions for China railway express. Transp. Res. Part E Logist. Transp. Rev. 2018, 117, 58-81. [CrossRef]

44. De Vergeron, K.L. The New Silk Roads: European Perceptions and Perspectives. Int. Stud. 2018, 55, 339-349. [CrossRef]

45. Lobyrev, V.; Tikhomirov, A.; Tsukarev, T.; Vinokurov, E. Belt and Road Transport Corridors: Barriers and Investments; Eurasian Development Bank; Centre For Integration Studies: Saint Petersburg, Russia, 2018; p. 43.

46. Zhai, F. China's belt and road initiative: A preliminary quantitative assessment. J. Asian Econ. 2018, 55, 84-92. [CrossRef]

47. Goodman, C.M. The Delphi technique: A critique. J. Adv. Nurs. 1987, 12, 729-734. [CrossRef]

48. Van De, A.; Delbecq, A.L. Nominal Versus Interacting Group Processes for Committee Decision-Making Effectiveness. Acad. Manag. J. 1971, 14, 203-212. [CrossRef]

49. Durach, C.F.; Glasen, P.C.; Straube, F. Disruption causes and disruption management in supply chains with Chinese suppliers. Int. J. Phys. Distrib. Logist. Manag. 2017, 47, 843-863. [CrossRef]

50. Nitsche, B. Unravelling the Complexity of Supply Chain Volatility Management. Logistics 2018, 2, 14. [CrossRef] 
51. Schoenherr, T.; Modi, S.B.; Benton, W.C.; Carter, C.R.; Choi, T.Y.; Larson, P.D.; Leenders, M.R.; Mabert, V.A.; Narasimhan, R.; Wagner, S.M. Research opportunities in purchasing and supply management. Int. J. Prod. Res. 2012, 50, 4556-4579. [CrossRef]

52. Green, T.B. An Empirical Analysis of Nominal and Interacting Groups. Acad. Manag. J. 1975, 18, 63-73. [CrossRef]

53. Lloyd, S. Applying the nominal group technique to specify the domain of a construct. Qual. Mark. Res. Int. J. 2011, 14, 105-121. [CrossRef]

54. Larson, P.D. A note on mail surveys and response rates in logistics research. J. Bus. Logist. 2005, 26, $211-222$. [CrossRef]

55. Melnyk, S.A.; Page, T.J.; Wu, S.J.; Burns, L.A. Would you mind completing this survey: Assessing the state of survey research in supply chain management. J. Purch. Supply Manag. 2012, 18, 35-45. [CrossRef]

56. Rodemann, H.; Templar, S. The enablers and inhibitors of intermodal rail freight between Asia and Europe. J. Rail Transp. Plan. Manag. 2014, 4, 70-86. [CrossRef]

57. Johns, M.B.; Clarke, J.L.; Kerswell, C.; McLinden, G. Trade Facilitation Challenges and Reform Priorities for Maximizing the Impact of the Belt and Road Initiative; World Bank: Washington, DC, USA, 2018.

58. Zhang, J.; Wu, Z. Effects of Trade Facilitation Measures on Trade between China and Countries Along the Belt and Road Initiative; Springer Science and Business Media LLC: Berlin/Heidelberg, Germany, 2018; pp. 227-241.

59. Cai, S.; Jun, M.; Yang, Z. Implementing supply chain information integration in China: The role of institutional forces and trust. J. Oper. Manag. 2009, 28, 257-268. [CrossRef]

Publisher's Note: MDPI stays neutral with regard to jurisdictional claims in published maps and institutional affiliations.

(C) 2020 by the author. Licensee MDPI, Basel, Switzerland. This article is an open access article distributed under the terms and conditions of the Creative Commons Attribution (CC BY) license (http://creativecommons.org/licenses/by/4.0/). 